\title{
CHANGING SOCIAL ARRANGEMENTS IN STATE-TRADING STATES AND THEIR EFFECT ON INTERNATIONAL LAW
}

\author{
W. FrtedmanN*
}

\section{INTRODUCTION}

Just as government-controlled navies came to replace the once predominant privateers, so state responsibility for the conditions of trading has increasingly replaced uncontrolled free trade, both internally and internationally. The extent of this shift in the conditions of international trade is, however, still obscured by the fact that we tend to take note only of the open and obvious changes in the organization of trade, as they occur through the socialization of resources and agencies. Thus, it is obvious that the Soviet Union and the other Communist states conduct all their foreign trade under a general economic plan and through the instrumentality of state-controlled official agencies. But it is less obvious that a vast number of states exercises far-reaching control over the international movements of goods and services from and into their countries through a variety of instrumentalities, such as currency control, tariffs, import quotas, selective permits for the importation of raw materials, and the like. Exporters or investors of the capital-exporting countries are, of course, well aware of the range and complexity of these controls. There is, however, a tendency to identify them with the special conditions prevailing today in the underdeveloped countries-either by virtue of economic necessity, or as a result of their political philosophy blending elements of nationalism and socialism, or a combination of both.

The folklore of private enterprise and free trade, more than any other factor, still largely prevents many people in this country-though not abroad, where the effects of the restrictions are keenly felt and observed-from realizing the extent of the official regulation of trade in this country. Free trade versus state trade is still considered to be a vital aspect of the ideological struggle in the cold war, but such incantations hardly alter reality. Trade has largely become an instrument of national policy in all the countries of the world, although the extent to which this means actual interference with the conditions of trade depends on the prevailing economic conditions of the country, rather than on purity of ideology. At most, it could be said of this country that "its external economic policies have displayed a fundamental

* Dr. Iur. 1930, University of Berlin; LL.M. 1936, LL.D. 1947, University of London; LL.M. 1948, University of Melbourne. Professor of Law, Columbia University. Author, Australian Administrative Law (x950), Law and Sociat Change in Contemporary Britain (195i), Legal Theory (3d ed. I953), Introduction to World Politics (3d ed. I956). Editor, The Punlic Corporation (1954), Matrimonial Property Law (1955), Anti-Trust Laws (1956), [with R. C. Pugh] Legal. Aspects op Foreign INVESTMENT (1959). 
ambivalence, wavering between partial measures of international cooperation and the espousal of policies of protectionism."

A formidable case can be made for the proposition that United States economic policy-as indubitably that of the vast majority of other countries-has essentially been guided by national security and protectionist considerations, resulting in a battery of official directives and restrictions upon trade. This has been particularly noticeable in connection with the postwar economic involvements of the United States, such as Trade Agreements Extension Act of $1953,{ }^{2}$ the Foreign Assistance Act of $1948,{ }^{3}$ the various Mutual Security Acts, ${ }^{4}$ and the escape clause included in the General Agreement on Tariffs and Trade at the insistence of the United States. ${ }^{5}$ To these must be added the legislative controls imposed for specifically strategic and security reasons, such as the so-called Battle Act of 1951, which embargoes shipments of strategic materials to "any nation or combination of nations threatening the security of the United States, including the Union of Soviet Socialist Republics and all countries under its domination. ... se So powerful and varied is the armory of control mechanisms now at the disposal of the so-called free-trading states that, in times of war or grave emergency, a complete control over foreign trade in all its aspects can be imposed, without any need for socialization or revolutionary measures.

But while, from a functional point of view, the differences between state-trading and free-trading states appear to be greatly exaggerated, for purposes of legal analysis, they are still of vital importance. A private firm which, in order to conduct its export and import business, depends on a multitude of official permits and controls over supplies, exchange, and terms of payment still appears as a private subject conducting business, not as a state agency.

International law is predicated on the assumption of a general equilibrium of rights and obligations in the relations between the states which are the subjects of international law. In the field of international trade-in its widest sense-the tacit assumption has been that industry and trade are conducted privately, while governments confine themselves to the traditional functions of "nightwatchman" statesi.e., defense, foreign affairs, and certain police functions. It is only on this assumption that the present rules of neutrality in regard to supplies to belligerents or the rules governing the immunity of foreign states from jurisdiction can be understood. The increasing activities and responsibilities of governments in the conduct of trading operations-either direct, or through state instrumentalities, or through controls at one remove-have put an increasing strain on the working of these rules. But it

${ }^{1}$ Miller, Foreign Trade and the "Security State": A Study in Conflicting National Policies, 7 J. PuB. L. 37,47 (1958).

${ }^{2}$ Act of Aug. $7,1953, \S$ 103, 67 STAT. 472.

${ }^{3} 62$ Stat., 22 U.S.C. $\$ 1404(\mathrm{a}), \mathrm{r}_{404}(\mathrm{~b}), \mathrm{I} 409$, I9Io (I952).

*65 STAT. 373 (I95I), 22 U.S.C. \$ $\$ 509$ et seq. (I952); 66 STAT. 43, 22 U.S.C. $\$ \$ 272 b, 28 \mathrm{rb}$ et seq. (1952); 66 STAT. I4I, 22 U.S.C. $\$ \$ 286 \mathrm{~b}, \mathrm{I}_{503}$ et seq (1952).

'Cf. 65 Stat. 73 (195I), Ig U.S.C. $\$ 1363$ (I952); see 61 STAT. (5), (6) (1947), T.I.A.S. No. I700 (effective Jan. 1,1948 ).

'65 STAT. 645, 22 U.S.C. $\$$ I6II (1952). 
was only with the General Agreement on Tariffs and Trade that the difficulty of formulating commensurable obligations for parties which operate their fareign trade through state agencies, on the one hand, and those which have private enterprise on the other, became quite openly apparent. Only then was an attempt made to cope with the problem explicitly.

It is, however, essential to understand that the problem is both older and wider than GATT. Indeed, it is a failure to look at the phenomenon of state trading and state control of trading as a general and important concern of contemporary international law that has accounted for a great deal of confusion and vacillation in the approach to the various subdivisions of the problem. The following brief observations will deal with four different aspects of the problem: first, government immunity from foreign jurisdiction; second, the equilibrium of neutrality obligations in trading with belligerents; third, the legal status of the government-trading corporation as a legal entity distinct from the government; and fourth, the attempt to create common rights and obligations between state-trading and private-trading states in a multilateral convention, such as GATT. This will be followed by some brief observations on the ways by which tensions created by the discrepancies of social structure can be overcome, or at least mitigated.

\section{I}

\section{State Trading and Sovereign Immunities}

The principle of international law that foreign governments cannot be held subject to the jurisdiction of any municipal court of another country, because such assumption of jurisdiction would violate the principle of sovereign equality of the nations, has increasingly been strained, as one government after another has proceeded to engage in commercial transactions with international ramifications. Such activities and responsibilities extend far beyond the Sino-Soviet bloc. For example, the major shipping lines of Italy are government-controlled; and it is almost forgotten that during and following World War I, the United States Merchant Navy was state-owned. Certainly, the once prevalent theory that a state exercised government activities proper only as long as it did not enter trade ${ }^{7}$ has long been abandoned. Even in the United States, it has been repeatedly held that the exercise of economic and commercial operations is as much a proper government activity as any of the more traditional government functions. ${ }^{8}$

Unfortunately, however, from the correct premise that "when, for the purpose of advancing the trade of its people or providing revenue for its treasury, a government acquires, mans and operates ships in the carrying trade, they are public ships in the same sense that warships are," and that, in the opinion of the Court, there is "no international usage which regards the maintenance and advancement of the eco-

\footnotetext{
' See, e.g., Ohio v. Helvering, 292 U.S. 360 (1934).

${ }^{8}$ See, e.g., New York v. United States 326 U.S. 572 (1946) (the Saratoga Spring case); Berizzi Bros. Co. v. S.S. Pesaro, 271 U.S. 562 (1926).
} 
nomic welfare of a people in time of peace as any less a public purpose than the maintenance and training of a naval force," it has often been improperly deduced that the jurisdictional immunity of foreign governments must be extended to its commercial operations and assets. This is still the almost unchallenged jurisprudence of the courts in England, ${ }^{10}$ which, despite occasional judicial doubts, ${ }^{11}$ have refused to adapt the English judicial application of international law to drastically changed conditions. It is less emphatically maintained in the United States, where the so-called Tate Letter of $195^{2}$ stated the position of the United States Government to be that immunity should no longer be granted to foreign governments with respect to private acts (iure gestiones), and that "it will hereinafter be the Department's policy to follow the restrictive theory of sovereign immunity in the consideration of requests of foreign Governments for a grant of sovereign immunity."12 But the practical effect of this doctrine, which appeared to bring United States practice more into line with predominant continental practice, has since been somewhat attenuated. In a recent case, an American company, wishing to sue the Republic of Korea for damage caused to its steamer by a lighter belonging to the Republic of Korea, had attempted to establish New York jurisdiction by seizing the defendant's assets in a New York bank. This the Government declared to be an inadmissible interference with the privileges of a foreign sovereign. ${ }^{13}$ While not affecting the doctrine of qualified immunity as such, this decision certainly limits its practical application to situations where jurisdiction can be established in an ordinary manner and the foreign government may be expected to comply with an adverse judgment voluntarily.

The majority of continental countries has long adopted the doctrine of qualified immunity, ever since the decision of the Belgian cour de cassation in Ig03 showed the way. ${ }^{14}$ Generally, the doctrine of qualified immunity distinguishes between acts iure imperii and acts iure gestiones, but on the exact nature of the distinguishing tests, there remains controversy. For the reasons already outlined, any test which attempts to distinguish between "sovereign" and "nonsovereign" acts of government is fallacious. Even United States theory no longer maintains that governments, when engaging in commercial activities, do not act as "sovereigns." Neither is the test of the form of the transaction satisfactory. Without going into the details of this much debated question, it may suffice to say that the most satisfactory test yet developed

'Berizzi Bros. Co. v. S.S. Pesaro, 27I U.S. 562, 574 (1926).

${ }^{20}$ See, e.g., Krajina v. Tass Agency, [1949] 2 All E.R. 274 (C.A.); Rahimtoola v. Nizam of Hyderabad, [1957] 3 All E.R. 44I (H.L.).

${ }^{11}$ Such as those voiced by Lord Wright in Compania Naviera Vascongado v. S.S. "Cristina," [1938] A.C. 485 ; and by Lord Denning in Rahimtoola v. Nizam of Hyderabad, [1957] 3 All E.R. 44r, 463 (H.L.).

${ }^{12} 26$ State Dep't Bull. 984 (x952).

${ }^{13} \mathrm{New}$ York and Cuba Mail S.S. Co. v. Republic of Korea, 132 F. Supp. 684 (S.D.N.Y. 1955).

"For the most recent survey, see Schmitthoff, The Claim of Sovereign Immunity in the Law of International Trade, 7 INT't \& CoMP. L.Q. 452 (I958). 
is that.adopted in the Brussels Convention of 1926 by a number of continental states (but not acceded to by any of the major maritime powers), under which ${ }^{15}$

Sea-going vessels owned or operated by. States [and] cargoes owned by them . . . are subject in respect of claims relating to the operation of such vessels or the carriage of such cargoes, to the same rules of liability and to the same obligations as those applicable to private vessels, cargoes and equipments.

This is followed by specific exemptions for ships of war and other public vessels clearly not engaged in commercial operations. In other words, it is a test of the activity in question, the functional approach, which alone can lead to a satisfactory solution of this problem in an international society in which the trading responsibilities of governments cover the whole range of the spectrum, from remote and contingent control to direct operation. ${ }^{16}$.

The most important task is to maintain a reasonable equilibrium between rights and obligations in international legal relations. This cannot be done by simply extending the sphere of government immunities to include a vast range of formerly uncontemplated commercial operations. This greatly extends immunity for commercial operations for some states, but not others. On the other hand, few, if any, states would be willing to dispense with government immunity altogether in this age of particularly high national sensibilities and sovereign claims. A meeting ground can, therefore, be only found on a functional level-i.e., by judging the type of operation in question. It is towards such a middle ground that international law seems to be moving, albeit slowly and with insufficient support by the foreign offices and courts of some countries.

\section{II}

\section{State Trading and the Duttes of Abstention in the Law of Neutrality}

Customary international law assumes that trading activities are in the hands of private enterprises. Therefore, the customary rules impose on neutral states as such only the duty of abstaining from certain active operations, such as the granting of loans or the supply of war materials. ${ }^{17}$ But the international law, as formulated in the Hague Convention, does not forbid the citizens of neutral states to engage in commercial activities. Indeed, the supply of arms and other munitions of war has been an important source of sustenance for belligerents, especially where major industrial powers remained in a state of neutrality. To be sure, in the last two

${ }^{15}$ International Convention for the Unification of Certain Rules Concerning the Immunities of Government Vessels, Treaty Information Bull. No. 18, March 31, 1931, art. 1, p. 67.

${ }^{10}$ The more radical suggestion of the abolition in principle of governmental immunities, made by Lauterpacht, The Problem of Jurisdictional Immunities of Foreign States, 28 BRIT. Yв. INr'z L. 220, 250 (195I), does not appear to be practicable at this stage of development in international relations. Moreover, the qualifications admitted by Judge Lauterpacht himself, such as the activities of "armed forces," introduce the same difficulty of distinction between commercial and noncommercial transactions.

${ }^{17}$ See Hague Convention (XIII) Concerning the Rights and Duties of Neutral Powers in Naval War, Oct. I8, 1907, art. 6, 36 STat. 2428, T.S. 545 (effective Feb. 28, 1910). 
World Wars, the sphere of neutrality has become increasingly restricted, because all the major powers sooner or later became involved. At the same time, moreover, the concept of contraband-i.e., of goods liable to seizure-has expanded continuously to the point where the concept of noncontraband goods has become almost an extinct category. Hence, it would seem that this branch of neutrality has decreased in significance. It may, however, become more important under the conditions prevailing in our own days, when the fear of mutual destruction may, as we must fervently hope, prevent the world's major powers from engaging in direct war with each other, but when the possibilities of smaller wars between minor powers cannot be at all excluded. Under such conditions, it would become a matter of great practical as well as theoretical moment whether a state that directly controls production and trade in war materials should be subjected to stronger obligations of abstention than one in which these activities are carried on by private citizens. Over twenty years ago, the writer suggested that simply to apply the Hague rules of abstention to statetrading states would strain the equilibrium of international law to a breaking point, since it would tend to penalize a socialized or semisocialized country in its international operations. ${ }^{18}$ The situation is, in a sense, the inverse of that described in the sphere of government immunities.

It is, however, easier to denounce the inadequacy and unworkability of the rule of international law than to substitute a new one. For, just as the old rules were based on a tacit assumption of equivalence of economic organization in the member states of the family of nations, so a new customary rule would have to be based on common principles of economic organization, which simply do not exist at the present time. Thus, the Harvard study on neutrality, published in I939, while aware of the problem posed by the new developments, regarded widened duties of abstention on the part of state-trading states as the lesser evil and proposed an article expressly enjoining a neutral state to "abstain from supplying to a belligerent assistance for the prosecution of the war." Similarly, Sir Hersh Lauterpacht, in a more recent edition of Oppenheim's International Law, contends that states having trade monopolies must abide by the existing rules. ${ }^{20}$

Although on paper this is the simplest solution, it will almost inevitably lead to a breakdown of the rules of neutrality in this field. When the major industrial powers are themselves engaged in war, neutrality-certainly, in the field of arms and contraband supplies-is relegated to an inferior position. But, even when the major industrial powers are not themselves belligerents, they are, given the precarious balance of contemporary international politics, actively interested in almost any local conflict that may break out-in Vietnam, Jordan, Iraq, or Cuba. It is, accordingly, neither likely nor reasonable to expect that a state-trading power will feel

\footnotetext{
${ }^{18}$ Friedmann, The Growth of State Control Over the Individual and Its Effect Upon the Rules of International State Responsibility, I9 BRIT. YB. INT'L L. II 8 (1938).

${ }^{10}$ See Harvard Research in International Law, Draft Convention on the Rights and Duties of Neutral States in Naval and Aerial War, 33 AM. J. INr'L L. 237 (Supp. 1939).

${ }^{20} 2$ H. LAUTERPACht, Oppenheims's Internationai LAW 657 et seq. (7th ed. I952).
} 
bound by widened duties of abstention, nor will it passively watch a rival power sending vast supplies of arms and other vital material under the cover of outwardly private trade.

And even the cold logic of the rule is extremely doubtful. For as the experience of the last generation and the change in social organization, even in the free-trading states, have shown, there is not a state in the world today which cannot, and does not, in case of necessity, control the foreign trade flowing from and into its territory. Twenty-three years ago, the major powers of the Western and the Communist worlds had no legal or technical difficulty at all in concluding a nonintervention pact, with mutual obligations of abstention from supplying arms to either side in the Spanish Civil War. That the pact broke down was not attributable to any inability of any of the participating powers to implement its commitments by corresponding controls over its internal trade-which, indeed, have been exercised on many subsequent occasions, with complete success-but rather to basic political divergencies, which ultimately led to World War II. The fact that so-called freetrading states are today not only able, but expected to impose controls on their subjects, and that they have done so on many occasions, makes the extension of the old rules of neutrality so as to impose a far heavier burden on state-trading states even less acceptable.

A more realistic suggestion is that recently made by Julius Stone. ${ }^{21}$ According to Professor Stone, the equilibrium should be restored by assimilating the trading activities of neutral governments to private trading by relieving, on the one hand, neutral governments of their duties of abstention from supplies, loans, etc. to belligerents, and subjecting them, on the other hand, to the liabilities of search and seizure for contraband goods, to which private traders are exposed under the rules of international law. This proposal, while theoretically elegant, meets, however, with the practical difficulty, that neutral governments are unlikely to tolerate search and possible seizure of their own vessels by the armed forces of belligerents, and this would be particularly unlikely in the most practical contingency-namely, of major industrial powers being neutrals and smaller powers being belligerents. Perhaps this difficulty could be somewhat mitigated where the government's trade is carried not in directly government-owned vessels, but through the instrumentality of semiautonomous state-trading corporations, on which some further observations will be offered below.

For the time being, however, it would seem that the only realistic hope lies in ad hoc solutions-such as were attempted in the Spanish non-intervention agreement $-i . e$. , in agreements between a number of states concerned in a particular situation. In such cases, it may be possible to obtain agreement on total abstention or on limitation of supplies to certain categories of goods. But it is certainly too early to look, at this stage, for a new universal rule of international law, as it is unrealistic to believe that the old rules, as formulated in the Hague Conventions, can effectively survive.

${ }^{21}$ Julius Stone, Legal. Controls of International Conflict 408 et seq., 413 (r954). 


\section{III}

The Status of the Government-Trading Corporation in International Law

The failure to see the problem of changing social functions of government in its entirety has led to a particularly noticeable confusion and vacillation of thinking in regard to the government-trading corporation. This institution has developed in a large number of countries out of the need to combine, in the words used by President Roosevelt in his message to Congress of r933, asking for the establishment of the Tennessee Valley Authority, 22

a corporation clothed with the power of government but possessed of the flexibility and initiative of a private enterprise.

It is, therefore, a deliberate combination of public and private law aspects. Machinery and personnel of government bureaucracy were found increasingly unsuitable to establish and manage complex industrial and commercial enterprises on behalf of the government. Hence, it was particularly important for legislators, in the creation, and for courts, in the interpretation, of the status of these corporations to reflect on the extent to which, given their purposes and functions, they should be clothed with public or private law attributes.

Such systematic thinking on the status of public commercial enterprises has gone farthest in Great Britain, in connection with the postwar nationalization of basic industries. A somewhat comparable development has taken place in Franceagain, in connection with the postwar nationalization of certain industries and utilities in the form of établissements publics. In other continental countries, such as Italy, where public commercial enterprise is of great importance, the form is less clearly characteristic, since government trade operates mainly in the form of stock companies in which the Government has the controlling interest. In the United States, where publicly-owned enterprises, such as the Tennessee Valley Authority, have a form comparable to the British pattern, clear legal thinking on their status has been obscured by the widespread prejudice against the very concept of public enterprise and the unfortunately successful attempts of Congress, in the Federal Tort Claims Act of $1946,^{23}$ to shackle the federal public corporations closely to the budgetary control of a politically-minded and pressure-sensitive Congress. ${ }^{24}$

It is, nevertheless, possible at this stage to distil from the manifold forms of statetrading enterprises in a large number of countries certain characteristics. In a summary of the analysis attempted by the present writer elsewhere, ${ }^{25}$ a recent writer,

297 Cong. Rec. 1423 (1933).

${ }_{23}^{20} 60$ STAT. 843 (I946), 28 U.S.C. $\$ \S 129 \mathrm{I}, 1346$, I402, I504, 2II0, 240I, 2402, 24II, 24I2, 267I-80 (1952).

"For a far more enlightened and systematic concept of the status of the public corporation in the State of New York, see the recent New York Temporary State Commission, Report on Public AUTHORITIES (I956).

${ }^{25}$ Friedmann, International Public Corporations, 6 Mod. L. Rev. I86 (I943); see also, for a later and more detailed analysis, Friedmann, $A$ Theory of Public Industrial Enterprise, in A. H. Hawson (ED.), Public Enterprise 11 (1955); and the Comparative Analysis, in W. Friedmann (Ed.), The Public Corporation 539 et seq. (1954). 
defining the term "state-trading enterprise," used but not defined in the General Agreement on Trade and Tariffs, has described the main features as: ${ }^{26}$

... autonomy of legal and financial status, non-political management, long-term financing by government appropriations by shares subscribed by the government and absence of control by private shareholders, this latter being exercised by government departments. To come under the category of "public commercial enterprise" these agencies should carry on trade on behalf of the government.

According to the above definition, however, trading enterprises owned mainly or wholly by public authority are public commercial enterprises, provided that either the member concerned declares that it has effective control over it, or assumes responsibility for it. ...

This definition includes not only the public corporation proper-i.e., the public commercial enterprises specifically established for the purpose of carrying out certain government purposes-but also those commercial companies in which the government has acquired a controlling interest. This is entirely proper, since the accident of legal form should not determine the legal status of the enterprise in international relations.

If the courts of the different countries in which, in connection with particular litigation, the status of such enterprises had to be established, had reflected on their status in connection with the wider problem of government immunities, they should clearly have come to the conclusion that the device of the trading enterprise as a separate legal entity was to be understood as separating, for purposes of legal liability, that enterprise from the general status of government. Since it is generally regarded as desirable that the sphere of government immunities should at least not be extended beyond its original meaning, such an interpretation-which, incidentally, corresponds to that laid down internally for the public corporations of Great Britain, the dominions of the British Commonwealth, and the public authorities of the State of New York-would have neatly and elegantly disposed of the problem of government immunities in regard to commercial trading enterprises.

In the many countries where the former doctrine of absolute immunity has been replaced by that of qualified immunity-i.e., where commercial state operations do not partake of governmental immunities-the problem is not so serious. It is, however, serious in countries such as Great Britain or the United States, where a doctrine of qualified immunity has, as yet, not been clearly developed. Unfortunately, the courts in these countries have either wavered or altogether failed to grasp the problem. Thus, in the most recent English decision on the subject, the Court of Appeal applied the doctrine of immunity of foreign governments from national jurisdiction to a Spanish Government corporation charged with the import and export of grain for the Government. ${ }^{27}$ And in a previous decision, which rested primarily on the assumption that the Tass Agency was not a separate corporation, but

\footnotetext{
${ }^{26}$ V.A. Seyid Muhammad, The Legal Framework of World Trade 229 (1958).
}

${ }^{27}$ Baccus S.R.L. v. Servicio Nacional del Trigo, [1957] I Q.B. 438 (C.A.). 
a part of the Soviet Government machinery, one of the justices specifically made the applicability of the immunity doctrine dependent on whether the enterprise was constituted in the form of a public corporation proper (immunity applicable) or of a joint-stock company controlled by the Government (immunity nonapplicable). ${ }^{28}$ This, of course, is a wholly unsatisfactory and formalistic distinction which can only serve to increase friction in international commercial disputes.

While occasional American decisions have taken a more enlightened approach, ${ }^{29}$ the majority of the United States courts, too, have failed to adapt the law to the new social facts. Thus, in Berizzi Bros. Co. v. S.S. Pesaro, ${ }^{30}$ the Supreme Court reversed the decision of a district court which had held an Italian merchant vessel, owned and operated by the Italian Government and engaged in carrying olive oil from Italy to the United States, subject to a libel in rem. While affirming correctly that the carrying on of trade by a government was a public purpose, the Court deduced from it that the immunity had to be applied. Again, in a more recent decision of a district court, immunity was granted to the Anglo-Iranian Oil Company, on the ground that the British Government held a controlling interest in its voting stock and that the purpose of the company was to ensure oil supplies for the British Navy. ${ }^{31}$

The prevailing traditional approach of the common-law countries, which has just been referred to, is clearly undesirable as well as illogical from the point of view of international law. In the present state of international society, international law must aim at maintaining or developing rules that ensure the general equilibrium of rights and responsibilities among states that differ widely in their political and economic philosophies and organizations. It is neither possible nor desirable for international law to outlaw or discriminate against state-trading enterprise. Such an attempt would only disrupt what remains of international community. Neither is it desirable, from an international legal point of view, that the accident of public control of a commercial operation should confer a privileged status, through exemption from legal responsibility. The answer which has been tentatively provided by the Brussels Convention for any government-owned vessels is even simpler and more obvious in the case of separately constituted state-trading corporations. For purposes of legal status and liabilities, they should be held quite clearly distinct from the government for which they act. Since there is little prospect of a general international convention on this matter, however, it can only be hoped that the courts, and in particular the courts of the common-law jurisdictions, will modify a legal theory which has neither logic nor justice.

${ }^{28}$ Krajina v. Tass Agency, [I949] 2 All E.R. 274 (C.A.).

${ }^{30}$ E.g., United States v. Deutsches Kalisyndikat Gesellschaft, 31 F.2d r99 (S.D.N.Y. I929), where an agency for the sale of potash controlled by the French Government was held to be a commercial concern and, therefore, not within the ambit of government immunities.

${ }^{30} 27$ U U.S. 562 (1926).

${ }^{31}$ In re Investigation of World Arrangements with Relation to Production, etc., of Petroleum, Io7 F. Supp. 628 (D.D.C. I952), $x_{3}$ F.R.D. 280 (1953). The majority of the American decisions is in accord. See the note in W. W. Bishop, Cases and Materials on International Law 427 (I953): 


\section{State Trading In GaTT}

In one sense, the status of state trading in a multilateral convention such as the General Agreement on Tariffs and Trade, which attempts to lay down rules binding on a large number of states, ensuring fair play and nondiscrimination in international trade, forms part of the wider problem with which we have dealt so far: how to deal with the discrepancies in economic organization between the nations in such a manner that neither private-trade nor state-trade states enjoy discriminatory advantages in relation to each other. In another sense, however, GAT'T presents a different problem. For here-for the first time, as far as we are aware-the need to lay down general rules of conduct made it necessary to face the problem of statetrading directly and articulately.

The basic principle of GATT is that of nondiscrimination, and the main instrument for carrying out this principle is the most-favored-nation clause. Accordingly, article seventeen provides that state enterprises established, maintained, or granted by a contracting party must, in purchases or sales involving import or export, act on the principle of nondiscrimination. This means that the purchases and sales by state-trading enterprises shall be conducted on "commercial considerations"-i.e., that they should be directed by such factors as price, quality, availability, marketability, and transportation-and that the enterprises of other contracting partiesi.e., private traders-must be afforded adequate opportunities to compete in the purchase or sale in accordance with customary business practices. Conversely, no contracting party must prevent any enterprise-state or privately-owned-from acting in accordance with these principles.

Brief reflection on the basic differences in the motivation and operation of foreign trading in state-trading states and private-trading states-even those latter which, like the great majority of contemporary states, support private trading by subsidies, quotas, tariffs, and the like-shows how difficult it is, in effect, to apply the principle of nondiscrimination.

For an international economy which is at least basically directed by private-enterprise and free-trade ideals, the most important single instrument of legal support for an expansion of international trade has been the most-favored-nation clause. As formulated in article one of GATT, this means that ${ }^{32}$

any advantage, privilege or immunity granted by a contracting party to a product originating in or destined for any other country ... should be immediately and unconditionally accorded to similar products originating in or destined for the territories of all other contracting parties.

The most-favored-nation clause does not, as such, lead to a direct increase of trade between two or more states. But by guaranteeing equality of treatment to rival commercial states in the markets of a third state, and by thus eliminating dis-

${ }^{32}$ See, for a recent survey, Seyid Muhamasad, op. cit. stupra note 26, c. 5. 
criminatory burdens, especially those imposed through tariffs and customs duties, the clause serves to expand international trade under free-market conditions. Any concession, any advantage granted, under free-enterprise conditions by one state to another would extend to the commercial enterprises of any other state benefiting from the clause. The duty of the government under the clause is, in free-trade conditions, essentially one of abstention; the obligation is not to interpose obstacles to the trade flowing between private parties.

But a state which conducts its own trade, through the government itself or through state-controlled corporations, buys and sells, lends or borrows, supplies or hires services, as part of an official economic policy. It tends to operate by way of specific agreements which implement this policy: by barter deals, by special loan or technical assistance agreements, by bulk purchases or sales. Hence, the most-favorednation clause cannot have the same meaning for such a state as it has for a differentlyorganized state. Thus, the first commercial agreement between the Soviet Union and the United States, of July I3, I935, accorded most-favored-nation treatment (except for purchase of coal) to the Soviet Union in the American markets, but the Soviet Union, instead of reciprocally responding, was asked to commit itself to purchase in the United States commodities of a specified value within a given period. ${ }^{33}$ The British-Soviet Commercial Agreement of April I930, too, attempted to restore a measure of meaning to the most-favored-nation treatment of a state-trading partner by a protocol, in accordance with which the parties undertook to eliminate from their mutual economic relations all forms of discrimination and to be "guided in regard to the purchase and sale of goods, in regard to the employment of shipping and in regard to all similar matters by commercial and financial considerations only...." The subsequent denunciation of the Agreement was explained by a British Cabinet member in the following words: $:^{34}$

It is impossible to work a normal most favoured nation clause as an automatic piece of commercial policy, when, on one side, you have a private individual acting as a trader, merchant, broker, shipowner, and so on, and on the other side a State which can control the whole of the commercial transactions into and out of a country.

In the words of a recent commentator $:^{35}$

The clause cannot operate to encourage expansion of trade by opening markets on a nondiscriminatory basis to low-cost producers because factors other than cost and tariffs influence the decisions of state-trading buyers. In short, the most-favored-nation clause has proved itself to be no longer a sufficient desideratum for private-enterprise states in their commercial relations with state-trading states to constitute a quid pro quo for important tariff concessions by private-enterprise states.

Yet, the state-trading nations of the Sino-Soviet bloc have been insistent on the use of the most-favored-nation clause-for example, in a recent Soviet proposal to in-

${ }^{33} 49$ StAT. 3805 (1935), E.A.S. No. 8I (effective July I3, 1935). Cf. Domke \& Hazard, State Trading and the Most-Favored-Nation Clause, 52 'AM. J. INT'L L. 55, 57 et seq. (1958).

${ }^{34}$ Lord Runciman in 286 H.C. DEB. (5th ser.) 129 I-92 (1934).

${ }^{\text {as }}$ Hazard, Commercial Discrimination and International Law, 52 Ax. J. INT'z L. 495 (1958). 
clude an unconditional most-favored-nation clause in an All-European Agreement on Economic Cooperation. ${ }^{36}$ They have explained this desire as an expression of the principle of sovereign equality in the relations of nations, as a symbol of nondiscrimination, rather than an instrument of active expansion of trade..$^{37}$ But after the unsuccessful experiments of the interwar period, it is unlikely that a general agreement on these lines, between state-trading nations and the others, will be possible. General trade agreements, such as GATT, based on the most-favored-nation clause are likely to remain limited to states and share at least a minimum of common organization and principles in the conduct of trade. And even in the relations between these states, serious rifts have already occurred, because some of the parties depart more significantly than others from the principle of free trade and equality of opportunity-for example, through the granting of special subsidies to agriculture. In an insecure and tense world, preoccupied with cold-war strategy and defense considerations, the tendency is, in many ways, more strongly towards the Soviet principle than towards free trade.

As for the relations between private traders and state traders-at least those statetrading nations that are politically divided from the private-trade nations-international economic relations are likely to develop, if at all, on the basis of quid pro $q u o .^{38}$ In fact, only one state-trading nation (Czechoslovakia) is a party to GATT, and "no one as yet has been able to envisage a way in which to extend the specific commitment system of purchases to the multilateral level."30 Any retention of the most-favored-nation clause in relations between state-trading nations and others has political rather than economic significance. It emphasizes the principle of equality of opportunity. ${ }^{40}$ But the actual trade relations between such states will be governed by specific agreements for the purchase and sale of fixed quantities of goods. ${ }^{41}$ Such agreements, however, mean inevitably, for the purposes of the bilateral agreement, a departure of the private-trading states from their professed standard. To the extent that a state commits itself to the purchase or sale of certain quantities of goods, it abandons the principle of free trade-and of private enterprise-even though it may fulfill the agreement through subcontracting. In so far as it is possible to restore at all the equilibrium of international obligations in the trading

${ }^{30}$ Economic Commission for Europe, U.N. Doc. No. E/ECE/270, pt. I (1957).

${ }^{37}$ See the arguments as reported by Hazard, Commercial Discrimination and International Latv, 52 AM. J. INr'L L. 495 (1958).

${ }^{3 s}$ Although the Finnish-Soviet treaty of 1947 contains the most-favored-nation clause, the really important provision is that "the Government of the Contracting Parties will from time to time enter into negotiations for the purpose of concluding agreements defining the size and charter of mutual delivery of commodities. ..." Art. I.

${ }^{39}$ Domke \& Hazard, State Trading and the Most-Favored-Nation Clanse, 52 AM. J. INr'L L. 55,68 (1958).

${ }^{10}$ See Schwarzenberger, The Most-Fayored-Nation Standard in British State Practice, 22 BRrT. Yz. Int'z L. 96, II3 (I945); Robert R. Wilson, The International Law Standard in Treaties op the United States 246 (1953).

${ }^{1}$ Cf. Seyid Muhammad, op. cit. supra note 26 , at 240 . 
relations between state-trading and other states, it can happen only by the acceptance of obligations incompatible with the principles of free enterprise.

The difficulties of maintaining an equilibrium of rights and obligations, or even a comparable meaning of concepts, such as "commercial and financial considerations" or "most-favored-nation treatment" between states of basically different economic organization are likely to lead to an increasing disintegration of universal trading agreements and a corresponding intensification of trade relations between more compact groups of states linked by common interests and principles.

\section{$\mathrm{V}$}

Some Practical Devices for Bridging the Gap Between State Traders and Private Traders

As we have seen, it is unlikely that a general and multipurpose agreement, such as GATT, can provide more than a theoretical bridge between the diverging principles and policies that govern the planned economies, on the one hand, and the more or less private economies, on the other. The principle of nondiscrimination may apply in form, but not in substance. Where state-trading enterprises form part of a mixed economy, as they do in the majority of Western countries, it is possible to fit them into a general scheme of nondiscriminatory trading. As we have seen, a more determined modification of the traditional principles of government immunities and a more enlightened interpretation of the status of government-trading corporations would go a long way towards eliminating present inconsistencies and injustices. Given the elimination of such inconsistencies, it does not matter greatly whether the Italian shipping lines are operated by a government-controlled company or a privately-controlled company. Neither does it make any legal difference whether the-legally fully liable-National Coal Board of Britain or a private colliery sells or buys coal abroad. The decisive groupings in international trade are more and more directed by principles of politics rather than economics. While, on the one hand, a Sino-Soviet trading bloc is developing, in which trade circulates mainly within the bloc, with only relatively marginal trade taking place outside it, similar developments are, more tentatively, taking shape in the non-Communist world.

The counterpart to the Sino-Soviet trading bloc, whose members all regard trade as an adjunct of state policy, is not so much GATT as the evolving European Economic Communities. In the first of these, the European Coal and Steel Community, a joint supranational authority, controls and supervises the conditions under which trade in coal and steel flows between the participating industries. Certain strains have resulted from the fact that some of them are publicly and others privatelyowned. In the second, the European Atomic Energy Community (Euratom), the Commission exercises managerial and operating as well as regulatory functions. In the third and most ambitious, the Economic Community, the Commission super- 
vises, above all, the implementation of the free-trade and investment provisions. In all of them, a strong community of political purpose and economic organization is the indispensable prerequisite. Beyond the more closely-knit West European Communities, there are the looser ties between a wider circle of Western states, through the Organization of European Economic Cooperation (OEEC) and the as yet open, evolving Free Trade Area, which would comprise the West European Community of the six states and the wider group of OEEC nations.

Outside these evolving groupings of states, which are directed primarily by political rather than economic considerations, contacts and tensions between statetrading organizations and private traders are likely to arise mainly in the field of international investment, where industrially-developed countries confront either the government or a state-controlled organization of the capital-importing countries. Such is the case in a majority of the underdeveloped states which are now striving for rapid industrialization-states such as India, Burma, Ghana, Egypt, or Israel. In this group, there are also a number of Latin American states, where the government controls basic industrial and commercial developments, as it does, for example, in Brazil and Mexico. In all these states, the government plays a considerable and, in some cases, a decisive part in the economic process. In some states-e.g., Indiacertain vital industries are reserved to the "public sector," and they are, therefore, owned and operated directly or indirectly by the government. In many countries, credit and finance are largely in the hands of public development corporations. ${ }^{42}$ In other countries, notably in most of the oil-producing Arab states, the government is still largely identical with an autocratic ruler. In all these situations, economic transactions, of investment, production, trading, can only be placed on a satisfactory basis by specific treaties or agreements of a mixed public-private character. One model is provided by the series of recent friendship, commerce, and navigation treaties concluded by the United States with a number of countries, and typically providing for the principle of national treatment with respect to engaging in business activities and all the ancillary operations. ${ }^{43}$

In so far as activities, because of national sensitivities, are excluded from the national treatment principle, the most-favored-nation treatment ensures a status at least

\footnotetext{
42 Such as the Nacional Financiera of Mexico, which also directly participates in industrial enterprises.

${ }^{13}$ A typical clause, as first formulated in the treaty of 1949 between the United States and Uruguay, S. Exec. D., 8Ist Cong., 2d Sess. art. 8, para. I (1950) is as follows:

"Nationals and companies of either Party shall be accorded national treatment with respect to engaging in all types of commercial, industrial, financial and other business activities within the territories of the other Party, whether directly or by agent or through the medium of any form of lawful juridical entity. Accordingly, such nationals and companies shall be permitted within such territories: (a) to establish and maintain branches, agencies, offices, factories and other establishments appropriate to the conduct of their business; (b) to organize companies under the general company law of such other Party, and to acquire majority interests in companies of such other Party; and (c) to control and manage enterprises which they have established or acquired. Moreover, enterprises which they control, whether in the form of individual proprietorships, companies or otherwise, shall, in all that relates to the conduct of the activities thereof, be accorded treatment no less favorable than that accorded like enterprises controlled by nationals and companies of such other Party."
} 
as favorable as that enjoyed by other aliens. ${ }^{44}$ Equally important for the encouragement of relations between private enterprise and governments are the clauses in the same type of treaties that guarantee the property of foreign subjects against expropriation, "except for public purpose," and promise "prompt payment of just compensation." ${ }^{45}$

For further attempts to bridge the gap, we must look to a variety of bilateral agreements made for a specific purpose. To quote but one example, some years ago the Indian Government entered into three parallel agreements with major foreign oil companies for the construction of oil refineries in India-which are, in principle, reserved to the public sector. In these agreements, the Indian Government gave certain promises for import of the necessary raw materials and other facilities for marketing, exchange, etc. It also promised that it would not expropriate the enterprise for a period of twenty-five years and that there would be "reasonable compensation" in case of any expropriation thereafter.

We shall also have to look at the large number of bilateral concession agreements between a sovereign government and a foreign investor for the slow and halting development of international legal principles governing international investment. The first-and cardinal-principle-yet far from established-is that agreements between a government-or a government-controlled corporation-and a foreign private investor should come to be controlled by firm legal principles, modeled on the general principles of law-and, in particular, of contract-as recognized by civilized nations. This would be part of the increasing blending between public law and private law in the field of international economic transactions. This matter is still obscured by insistence on the principle of national sovereignty, which should come to be held as inapplicable to the field of agreements in the area of foreign investment for economic purposes as it should come to be outmoded in the area of government immunities.

Here, as in the other areas which we have briefly surveyed in this article, it must be recognized clearly that for many years to come, international society will display a vast variety of forms of economic and social organization, ranging from the complete control of all economic activities to systems dominated by private enterprise and trade. Unless there is to be a complete severance of ties between diverse groups of nations, a severance which would increase the already vast political schism, working compromises must be found; and the only rational basis for such compromises can be equality of treatment and status for the purpose at hand. This means that government and private enterprise must, for the particular investment transaction or litigation, meet, as far as possible, on a plane of equality. Such equality implies that,

\footnotetext{
"For a survey and analysis of the friendship, commerce, and navigation treaties, see Walker, Treaties for the Encouragement and Protection of Foreign Investment: Present United States Practice, 5 AM. J. CoMp. L. 229 (1956).

"5 As for the effectiveness of nonexpropriation promises in international law, reference must be made to the vast literature on the subject. See, e.g., Fatouros, Legal Security and International Investment in W. Friedmann \& R. C. Pugh (Eds.), Legal Aspects of Foreign Investment 699 (I959).
} 
on the one hand, governments charged with duties of abstention-as in the law of neutrality-must not seek refuge behind the assertion that they cannot control private trade-an assertion which would in any case be hypocritical in modern conditions; and, on the other hand, governments should not be accorded privileges in relation to private traders because of the identification of their trading enterprises with the state.

We need a far clearer separation than has hitherto been evolved between the legitimacy of economic state activities as a function of government and the submission of government-trading activities to the ordinary legal processes of full liability and accountability. Where government and private enterprises meet for a particular purpose, as in the development of a new utility or industry in an underdeveloped country, they can iron out the differences, either in the framework of a basic treaty that ensures national treatment and protects against discriminatory interference with property, or through a specific ad hoc agreement, such as is contained in modern concessions. In other words, international law and relations in this field can develop mainly in a series of $a d$ hoc compromises, out of which, in time, a general body of principles of international economic law may evolve, compounded of the traditional principles of public international law and the principles that have been shaped in the private law of contracts, tort, and property. 